\title{
SCIENCE AS AN OBJECT OF SOCIOLOGIAL STUDY
}

\author{
Jorge Bartolucci \\ Universidad Nacional Autónoma de México
}

https://doi.org/10.33676/EMUI_nomads.55.14

\begin{abstract}
Science as an object of sociological study" presents a theoretical reflection about the attributes of science that makes it a sociological matter of interest. Since science operates in a world composed of strong territorial, linguistic, cultural and political / ideological differences, it has been in the midst of a controversy between those who maintain that it is determined by social factors and those who conceive it as an entity that develops with a relative autonomy of them. The article argues that the tension between one conception and another diminishes when conceiving the rigorousness that distinguishes scientific methodology, not only as cognitive rules but also as symbolic ways which have been created and shared socially to materialize the consubstantial ethical principles of scientific rationality.
\end{abstract}

Keywords: Sociology ff Science, Scientific Knowledge, Scientific Method, Ethic of Science

\section{La Ciencia Como Objeto de Estudio Sociológico}

Resumen.- "La ciencia como objeto de estudio sociológico" presenta una reflexión teórica sobre los atributos de la ciencia que la convierten en una cuestión de interés sociológico. Dado que la ciencia opera en un mundo compuesto por fuertes diferencias territoriales, lingüísticas, culturales y político / ideológicas, ha estado en medio de una controversia entre quienes sostienen que la misma está determinada por factores sociales y aquellos que la conciben como una entidad que se desarrolla con una relativa autonomía de ellos. El artículo argumenta que la tensión entre una concepción y otra disminuye al concebir la rigurosidad que distingue a la metodología científica, no solo como reglas cognitivas sino también como formas simbólicas que se han creado y compartido socialmente para materializar los principios éticos consustanciales de la racionalidad científica.

Palabras clave: Sociología de la Ciencia, Conocimiento Científico, Método Científico, Ética de la Ciencia.

\section{The Social Character of Science}

Science has been in the midst of a controversy framed by two basic problems: the first one requests about how and to what extent scientific activity is facilitated or inhibited by social factors such as politics, 
economics and religion. The second one, questions about how science operates as a relatively autonomous social system of territorial, linguistic, cultural differences and of the political/ideological systems that prevail in the world. In order to contribute in some measure to the elucidation of this problematic dispute, I will present a theoretical point of view about the social character of science, an essential premise for visualizing the attributes that make it a sociological matter of interest or, if preferred, an object of study of sociology. I clarify that I do not intend to make a state of the art of the debate on this topic. It is only a highly selective review of classic and contemporary authors, whose approaches not necessarily sociological are in my opinion convergent, in the understanding that from different positions and in some cases very reluctantly, point to delimit the reasons why science deserves and should be considered a social construction. The main objective in this sense is to specify what I mean by assuming that science must be considered a social fact.

I shall begin by saying that science is a specific form of human activity consummated by persons accredited as experts in the production of a special type of knowledge. From a historical point of view, the interest in this kind of knowledge would lie in studying the evolution of theoretical and operational concepts in the empirical sciences and in the impact of certain theoretical corpus, which have transformed our way of explaining the surrounding physical and social reality. Instead, philosophy would aim to address them by focusing attention on the criteria underlying the generation and validation of the knowledge produced, identifying its scope and limitations according to the logical and operational structures inherent in the processes of intellectual approach to observed facts. From the sociological perspective, is relevant to understand the specific social forms assumed by this human activity interested in producing a particular kind of knowledge. For this, it is necessary to study the meanings that nourish the professional interaction in its habitual environment and support the forms of work established there, as well as the criteria and modalities that govern the exposure to the criticism and the validation of its results. Each social environment establishes forms of interrelation that integrate its members into a special system of communication with its typical regularities of functioning and development. Such as those of the scientific milieu, which are intertwined in the internal structure of science and are not susceptible of being reduced to other aspects (Yahiel, 1975). It is indispensable to apprehend them in their own environment, as ways of communicative action that make up a determined world of life; in other words, a cultural institution sustained and nurtured by a sui generis social system.

The characteristic that most differentiates the scientific field is the degree of autonomy that it has in relation to others (Bourdieu, 2003). It should not be forgotten that the experts are the ones who, after all, promote, sanction, validate and, at the time, create, reproduce or replace the scientific paradigms that make up the substratum of their vision of the 
world and their behavior in the attempt to know it (Ferreira, 2007: 4-5). By means of processes of appropriation of knowledge and selfless dedication to its development, scientists, as individuals or within their teams and laboratories, create the scientific capital, which is shared in a practical and symbolic way within its peers. (Bourdieu, 2003) The social character that permeates the professional life of their communities does not depend, ultimately, of factors such as economics and politics, for example. The social basis of its practice is a complex network of human actions, guided by representations ranging from models and beliefs to complex scientific theories, and which have an axiological structure of norms and values (Olivé, 2004: 75).

So, sociological attention towards its "scientific products" must be done in the light of the series of actions that take part in the process of collective constitution and validation of its labor; conceiving it as a cross-linking of material and symbolic actions that are substantive for those who share a frame of reference as peculiar as the scientific one. The technical support is not separate or alien to the societal structure, much less suppose that the former is the essence of science and the second something contingent. No ethnologist would make that difference when studying other cultures; he would not distinguish, for example, between "essentially Nuer", inaccessible to ethnographic analysis, and "Nuer social", which would be. All his analysis would aim to make the culture he studied comprehensible globally. If in the study of 'primitive' groups there is no problem in embracing their most eminent forms of knowledge and wisdom, why should science be different? (Iranzo, 1991: 239).

The tension provoked by the antinomies that beat science between a social pole and an intellectual pole, generate a lot of confusion regarding its constitutive nature. On the one hand, it is argued that its specificity and excellence lies in the fact that the products it illuminates, independently and without regard to the way they are produced, unquestionably fulfill all the requirements of logical rigor and formal consistency. The fundamental and the only thing to which attention should be paid is to the results produced; which are of such quality that it is necessary to ignore the social environment in which they were obtained. On the other, it is argued that the singularity attributed to scientific knowledge is not so much an intrinsic quality as a result of the way in which scientists themselves concretely exert science (Ferreira, 2008: 3-4).

From the point of view proposed in this essay, the tension between one conception and another differs as we conceive the rigorousness that distinguishes scientific products, (logical coherence, theoretical pertinence, thematic relevance, empirical consistency, disciplinary originality and argumentative congruence), not only as cognitive rules but as symbolic forms of materializing the ethical principles consubstantial of scientific rationality. They represent the vital instruments of a task specialized in the production of knowledge that makes 
effective the competition that socially presupposes the "scientific" status (Ferreira, 2007: 12). Ethical and technical dimensions are on the same level. Just as morality gives meaning, support, orientation and body to scientific activity, technical issues are the result of a social construction that has established validation parameters reserved exclusively to its competence. In order to illustrate this symmetry, nothing better than to extrapolate from Bloor's claim that in the scientific world logical prerequisite is a type of moral obligation (Nola, 2004: 158).

This way of regarding science is very much in line with Max Weber's (1994) conception of the establishment of the 'capitalist spirit' as a singular case of the growth of Western rationalism. The main thesis is that according to its ethical principles, capitalism should be considered a rational moderation of the instinct that naturally moves the appetite of human beings towards profit. Hence the private capitalist economy is rationalized on the basis of rigorous calculation, systematic order and achievement of the desired economic surplus. The relation that the modern capitalist system maintains with its functional characteristics is extremely appropriate due to the unavoidable link that these maintain with the capitalist organization of the work. The same degree of adequacy is also applicable to the ties that connect the moral and cognitive aspects of science, since scientific activity would maintain an equally close and convenient link with the ethical principles that govern and regulate forms of production, communication and validation of their products.

\section{The Sociological Perspective}

According to the main purpose of this paper I will consider a specific way to observe and analyze scientific phenomena as facts of social life. Such a way is based on the so classical sociological premise as simple, indeed, according to which social reality is an entity that has no meaning outside of itself besides that given by the subjects who produce and reproduce it (Weber, 1978). That is, that society has an immanent development, which is not governed by additional social determinants and is not due to any natural law or historical necessity. This theoretical approach assumes that social facts are the result of interaction between individuals who share social, economic, political and cultural specific contexts, but are perceived, valued and represented by them, from different social positions and views. It should be noted that humans are the only species capable of providing value and meaning to things, ideas and other men. According to the theoretical support of Alfred Schutz (1974b) the mere facts do not exist, it is always interpreted facts. Under this peculiar attribute, social reality takes on different textures and tones for humans that live and produce it daily. Through these constructions of meaning about everyday life we select the part of the 
daily reality that we recognize as our own, and interpret, represent, justify and express the world in which we live. These objects of thought motivate our behavior and help us orient ourselves within our social environment and interact with it. Inter subjective recognition of these representations is essential to guide our behavior in society and guide our actions.

As a result of this significant process of reality, the social world to which we belong acquires a structure of meaning that is sustained and socially empowered. Hence, the members of a particular community share a set of representations that contain the meaning it has for them to be who they are, to do what they do and to take certain practices; their daily life is constituted and reproduced in accordance with such ideas. Social experience is what it is and not any other, because the subjects who carry it out are understood or dissent by virtue of the reciprocal expectations configured under a common frame of reference that they find habitual. Practices are constituted as such by virtue of the weight of the representations that are made by their actors, while the representations are constituted in referents by virtue of the practices that configure them as a palpable reality. This constitutive reflexivity of social practices implies an inseparable conjugation of the practical and the cognitive (Ferreira, 2008).

The beliefs, doctrines, ideologies, myths, justifications, idealizations, explanations and theories that have been established and propagated by men to represent reality, constitute our knowledge of the world and that knowledge helps us to establish it as a coherent and meaningful world to orient ourselves within it. Such representations can take rudimentary forms, as the views and ideas expressed daily or more elaborate shapes, such as myths, ideologies, religions and even science itself. In this sense, both from a technical and symbolic point of view, scientific language is a sign of a specific cultural identity, as is that of any Australian or African tribe (Ferreira, 2008). The sociological perspective presented here, focuses specifically on the relationship of this knowledge, with specific social processes; issue that is present in any social research done, but it is particularly important when studying events that deal with intellectual circles and institutions where scientific knowledge is created and reproduced.

In this case, the observational aperture is closed and as a result, the focus falls on such spaces and experiences as a sociological problem. Let us agree with Weber (1994) that it is no coincidence that it was only in Western countries that science adopted the form and content that we know of today. The same thing happened with art, since only the West was allowed to be the cradle of printed literature and musical notation. Outside the West, there was no rational legal science and an administration that gave economic activity the technical-juridical accuracy that characterizes it. It is obvious that in each of these cases, it is a specific and peculiar rationalism of the civilization of the West. It is 
also true that in all spheres of life and everywhere processes of rationalization have been carried out and that what we may consider rational from one point of view may seem irrational from another. The peculiarity of its historical and cultural specificity is precisely which one or which of these spheres - scientific knowledge in this case - was rationalized in its moment and from what point of view.

Consistent with this reasoning, when we affirm that science is a social fact, we specifically refer to a "historical individual" whose rationality has been determined by the achievement of interactive processes of shared constitution of his reality. The empirical study of the social dynamics that houses this rationality has revolved around two constitutive questions, one is concerned with its origin and historical evolution and the other with what distinguishes it from other cultural institutions. Undoubtedly, the paternity of the answers that we are trying to give to them today belongs to the sociologist Robert K. Merton, whose work opened innumerable lines of research on the rise of modern science and the normative structure of the scientific community (Iranzo, 1991: 91).

\section{Sociology of Science: Robert Merton}

A little more than half a century ago, Merton began the study of science as a reality shared within the margins of an area of social life that is structured through values, rules and patterns of behavior that organize individual and collective action in a specific institutional context. In paying attention to the relationship of science and society in their double implication, such studies turned out to be not only novel for sociology, but also led to new reflections on the epistemic aspects, until then absolute exclusivity of classical positivism (Sarthou, 2013:5). One of the great successes of his writings was to draw attention to the reciprocal relations between society and science, since until then the attention devoted to the influence of science on society had been much greater than on the weight of society (Merton, 1964). Explainable fact, since the influence of science on society is an effect that is evident to all; on the other hand, the influence of society on the scientific community - in the rhythm of development, in the focus of interest and in the very content of science - is not easily perceived or accepted. At the root of these resistances lies the prejudice that recognizing the presence of sociological fact in science implies compromising its autonomy with respect to other spheres, such as ideology and politics (Merton, 1985; 1985). Merton attributed it to the belief that objectivity, a value so fundamental in the ethos of science, would be threatened since society's support for science comes from very different social structures, as well as the recruitment of scientific talents (Márquez and Vilaró, 2014). 
It is true that because of its universal character, science is exposed to very diverse social structures, a position that allows it to act with very high degrees of independence. But that should not lead one to think wrongly that it operates in a complete social void. Human societies are agglomerations of individuals that usually relate to each other through exchanges of goods, services and information within a geographically, historically, culturally and politically defined territory and, to a large extent, are tied to a linguistic thread. The scientific community, on the other hand, is a type of society that is not territorially delimited, does not share the same language or culture, and operates in very different political and ideological systems (Lomnitz, 1991: 45). In that context, the most distinguishing characteristic of the scientific field is the degree of autonomy that it possesses and, from there, the strength and form of the processes of belonging, admission and professional competence imposed on its active members and the aspirants to enter it (Bourdieu, 2003).

Indeed, the question that led Merton to draw his thesis was what would be the substance that gave consistency to an institution that, despite lacking the ordinary bonds of social cohesion, had a particularly high degree of integration from the beginning. His answers to this problem began to trace a new specialized field of sociological knowledge dedicated to analyzing the relations of interdependence that science, as a social activity responsible for a specific cultural production, maintains with the civilization and society that surrounds it (Merton, 1964: 617-919). To a certain extent this brought about a substantial change in the way of seeing knowledge, since it assumed that not only the error, the illusion or the falsified belief were socially and historically conditioned, but so were those qualified as true. While attention was focused on the social determinants of ideology, illusion, myth, and moral norms, it was quite clear that in the explanation of error or uncertified opinion were implicit factors of the time and the corresponding society. The hypothesis that Merton established is that even the truths had to be contextualized in relation to the historical society in which they appeared (Márquez and Vilaró, 2014).

This was how Merton embarked on a line of empirical, specifically sociological research, which was concerned with deciphering what had made science a sui generis entity among the institutions that produced culture. His studies on the origins of modern science and its subsequent rise to a position of cognitive preponderance were in that direction (Vessuri, 1991: 60). Located in seventeenth-century England, he wanted to see an idea implicit in Max Weber's work on the relations between primitive asceticism and capitalism; in the understanding that this aspect of the reform contributed to provide mobiles and channel the activities of men in a direction conducive to experimental science. The forms adopted by this relationship cannot be referred to here without moving too far from our subject. Let us just say that this movement of religious 
radicalization exalted to such an extent eschatological concerns that it led its followers to break with all the institutional mediations that the church had built to establish ties between God and men.

The anguish caused by the absence of an authority invested with powers to decipher the unfathomable divine designs, at a time when the greater concern of men revolved around the state of grace, made those reformist zealots forced to seek the indicators of their salvation in new referents. So solitude in the face of the all-powerful soon became individualism, skepticism, and methodical work that led men to find earthly ways on earth to glorify God and to recognize in them the evidences of their state of grace. The new mentality opened an insurmountable gap between reason and established authority figures. The prevailing spirit came to be dominated by calculation, discipline and professional dedication. Science gained new momentum in this context.

That is the historical form of the thesis. In its most general and analytical form, Merton argues that science, like all other social institutions, must be supported by group values if it has to develop. These values were understood under the concept of scientific ethos, term with which he referred to the complex of mandates and rules that every man of science considers obligatory. Not because the scientific ethics has a formal code of reference, but is inferred from the moral consensus of scientists expressed in usage and custom, as well as in the indignation that usually provoke the contraventions to the ethical rules of the group. These moral imperatives, transmitted by precept, by example, and reinforced by sanctions, are internalized to varying degrees by the scientist and demand attitudes of loyalty, adherence, and respect for them.

What are the central characteristics of the scientific ethos for Merton? The values that for Merton (1964) regulate scientific activity include 'Universalism', 'Communitarianism', 'Disinterest', and 'Organized skepticism'. 'Universalism' says that the claim to truth of statements must be subjected to impersonal, universal empirical tests. The value of scientific claims depends on their repetitiveness as a methodological standard. Communitarianism, on the other hand, refers to the fact that the institutional norms of science make its products part of the public domain, which are shared by all and owned by no one. 'Disinterest' dictates that the end of science lies in the persistent search for increased knowledge, an attitude indirectly rewarded by the recognition and prestige that the community gives to those who stand out in that work. The last value is 'Organized Skepticism', by which the scientific attitude is characterized by being contrary to dogmatism and forces to review the assumptions and results of research in the light of logic and observation. Hence, scientists are predisposed to doubt the value of any assertion or hypothesis and to suspend judgment on them until satisfactory confirmation has been obtained. (Merton, 1964: 638-647) 
Merton's emphasis on these moral imperatives is framed in the Weberian statement that "scientific truth is what it claims to be true for all those who want the truth" (Weber, 1978: 73) It is in such a moral sense that the activities associated with the production of that particular form of human knowledge would be subjectively linked by a value thread that links those who are part of the scientific community. The word 'science' thus refers us to a cultural product, the work of people strongly united around a set of principles that have established a specific social order, which they submit to the pursuit of their private interests. In terms of Mertonian reasoning, there is therefore no paradox in believing that even a rational activity as science is based on values and beliefs, just like any other human group. What differentiates scientists from other social groups is not the absence of values and beliefs, but the forms under which they give them legitimacy. I refer to academic criteria and procedures, formal or otherwise, through which scientists judge and validate the results of their work, a matter that leads us to the fields of philosophy and the history of science.

\section{Philosophy and History of Scientific Knowledge: Karl Popper and Thomas Khun}

According to his work, The Logic of Scientific Research, Popper (1977) argues that the rationality of science lies exclusively in the process of falsifiability. Such idea appoints toward the assertion that for any hypothesis to have credence, it must be inherently disprovable before it can become accepted as a scientific hypothesis or theory. Falsifiability says nothing about an argument's inherent validity or correctness. It is only the minimum trait required for being validated in a scientific manner; just a dividing line between what is considered science and what isn't. If an assertion is not susceptible of being falsified, like dogmatic proclamations, for example, there is no way to treat it in the same way as a scientific statement. So, any theory deserves to be considered scientific, unless it is plausible to be denied by contrasting it with evidence of certain relevance to the problem in question.

This attack on the positivist criteria of scientific demarcation can be summarized in a single sentence: "theories are never empirically verifiable" (Popper 1977: 39). The most important consequence of this postulate is that no one can demand that a system of scientific propositions be selected once and for all, in a positive sense, but that it is refutable by experience. That is, it is susceptible of selection in a negative sense, by means of contrasts and empirical tests. What characterizes the scientific method is its way of exposing to falsification the knowledge that is proposed as valid, subjecting it to the contrast of all conceivable ways. Its goal is not to try to save the life of the unsustainable knowledge, but, on the contrary, to choose the one who is comparatively more apt, 
subjecting all to the rougher struggle for survival. How you get to them does not matter, but the basics that hold you up against the criticism of your peers.

In view of the fact that scientific theories are not entirely justifiable or verifiable, the criteria that Popper proposes to trace the line between empirical science and metaphysics imply that the search for the objectivity of scientific statements has no place to rest except in the mechanisms of intersubjective testing. In this sense, he clarifies that his criterion of demarcation between science and metaphysics "must be considered as a proposal for an agreement or convention." The famous argument that his proposal does not offer scientific thinking rather than a conjectural statute, and it is left to the scientific community to decide which conjecture is better than another, reinforces this idea (Popper 1977: 49).

In drawing the discussion of the theory of the scientific method from the strictly logical, or rather formal, terrain, Popper's postulates point, quite in spite of himself, to a place close to Merton's conception. It is well known that Popper had important reservations about the social sciences and refused to accept Kuhn's idea of turning to sociology and social psychology in order to clarify the objectives of science and its possible progress (Otero 1998). In Essential Tension, Popper wondered how it was possible for spurious disciplines such as history, psychology, and sociology to provide us with a more complete understanding of scientific activity (Otero 1998: 57-58). But their call to define empirical science by its rules or norms, "by our way of dealing with scientific systems, by what we do with them and what we do to them" (Popper 1975: 158), appeals indefectibly to the good sense of the scientific community.

Faced with the possibility of differences in the appropriateness of such "agreements or conventions", Popper's (1977) own admonitions reinforce this point, by admitting that reasonable discussion of scientific controversies is only possible "between parties that have a common purpose in view "(Popper 1977: 37). To which he adds: "Of course, the choice of such an end must be, in the final analysis, the object of a decision that goes beyond any rational argument" (Popper 1977: 37). Clarification that is all the more significant to us in so far as it refers to a footnote that says: "I believe that a reasonable discussion is always possible between interested parties for the truth and willing to pay attention to each other" (Popper 1977: 37). By itself, the idea of 'agreements and conventions' between parties that have 'one purpose' or 'interested in the truth' refers to a community of interests similar to that quoted by Max Weber. But this would be unfeasible if there was no consensus on rules of the game which, according to their own theory of scientific method, can not claim formal or moral validity, which is to say social, a condition that consciously or not approximates their thinking to the sociological perspective. 
As for Thomas Kuhn (1970a), his work The Structure of Scientific Research revived the search for explanations about the distinctive aspects of scientific activity and renewed the discussion around the epistemological and social bases of scientific knowledge. The trigger was his intelligent question about whether it was pertinent to speak of scientific truths to refer to something that at any time the scientific community itself could agree was false. In response to this question, Kuhn proposed to speak of 'scientific paradigms' instead of 'scientific truths', referring to the universally recognized scientific achievements that provide the scientific community with tentative models of problems and solutions.

Within this innovative analytical frame of reference, it turns out that the meaning and the degree of truth that the scientific statements assume are decided within the framework of the rules that prevail in the expert community. In turn, the forms of work that originates from these rules result in a type of practices called 'normal science'. In the course of the regular development of science emerge some innovations that acquire a paradigmatic status, by virtue of their greater degree of relevance within a given field of study. This is attributed to the consistency they possess, both because of their internal logical coherence and the scope and ability to successfully predict unforeseen events or that are not deductible from other alternatives. Despite the hierarchy given to paradigmatic referents, Kuhn admitted that successive theories that dominate a field of knowledge could often be immeasurable, because their concepts were reciprocally incompatible. For example, classical and relativistic mechanics are immeasurable because they use irreconcilable notions of mass and time, among others, whereas Newton and Descartes celestial mechanics were commensurable because both shared identical notions of ether and force (Iranzo 1991: 42).

However, if immeasurability is a problem for philosophers, it is not a problem for scientists, since they have and use numerous ad hoc techniques to determine the usefulness of current theories. The fact that the logical and methodological rules do not have arbitral power in a dispute between immeasurable paradigms, does not mean that scientists, individually, lack criteria to choose. If so, they woúldn't do it or they would do it at random, which does not happen at all. The degree of identification with a paradigm hangs on the consensus of the community around originality, generality, meticulousness or its opposites, as well as the consequences it might have on specific areas of knowledge (Iranzo 1991: 51). The criteria vary locally, temporally, individually and collectively. There is no algorithm that allows them to choose between rival theories in a purely logical way. When two immeasurable paradigms compete, it is only possible to rely on the good judgment of the scientists to choose the most pertinent option to the case (Iranzo 1991: 52-53). There being no rule superior to the approval of 
the community of specialists, again the theoretical rationality of science gives way to the substantive rationality of the group (Kuhn 1971).

In summary, Kuhn (1980) agreed with Popper that the scientific method is exercised in the verification process rather than in the process of creation, and like Merton, he assumed that for this to happen there must be a shared moral substrate that acts as a regulatory framework. That said it is necessary to mention that for Kunn the answers to the links between science and society should not be sought in the function that fulfills the scientific ethos, but in what scientists do. To this end, he proposed to undertake empirical studies on specific scientific work, paying attention to the decisions that the experts make to solve their research problems under contextually situated circumstances. The questions that Khun (1977) asked in this regard were: How do scientists actually choose between competing theories? How should we understand how science progresses? How does science progress in fact? This leads to a description of a value system, along with an analysis of the institutions through which the scientific system is transmitted and strengthened. In his view, much empirical research is still needed before attempting to satisfy these unknowns, but whatever the answer, in short, the explanation will have sociological basis (Khun 1977: 266-292).

\section{Criticism to the Classical Sociological Perspective of Science}

In the 1960s, Mertonian hegemony began to be challenged by programmatic alternatives that sought to reverse what they considered to be an exaggerated dissociation of both, social and cognitive aspects (Vessuri 1991: 60). This turn of unquestioned post-Kuhnian inspiration favored the emergence of several lines of research that sought to renew the theoretical discussion and the sociological analysis of scientific activity. In part, this was because Merton's teachings were assimilated by the scientific milieu in a reversal of their original intentions. Merton's thesis that science was an institution that owed its existence to the express adherence of its members to a peculiar ethos, was reabsorbed in the very ideology of scientists, reinforcing the myth of its social autonomy and favoring a certain idealism with respect to which they would be immune to the contamination of economic or political factors (Valero 2004: 124). In addition, the existence of a normative structure of science based on the values proposed by Merton began to be taken with considerable criticism (Vessuri 1991: 60). Studies more or less tangential to those inspired by Merton began to reveal that these types of values turned out to be opaque to the observation and that in the foreground appeared, instead, the competition between the scientists for obtaining the greatest possible recognition among their colleagues, for example. 
As Hebe Vessuri (1991) summed up in his article Recent Perspectives in the Social Study of Science, the intellectual movement known as the new sociology of science, or 'strong program' was identified with a set of statements about the scientific activity formulated by a group of mainly English authors of the University of Edinburgh, around the figure of David Bloor, philosopher and mathematician interested in giving an empirical basis to his critique of scientific objectivity. He recovered the Merton's idea that not only error, illusion, or belief had social roots, but also the discovery of truth was conditioned by society and history. But in light of Kuhn's thesis, Bloor did not admit the existence of truths but of the beliefs that scientists agree to qualify as true. Barry Barnes, Steve Shapin, Bruno Latour, Steve Woolgar, Karin Knorr Cetina and Michael Mulkay joined the Bloor initiative. They tried to prove that unlike Merton's approach, the axiological dimension could not be considered as a rigid set of rules with a univocal and precise meaning that agents must understand and 'internalize', and then act in accordance with them. Rather, scientific practices are manifested in a series of actions such as investigating, observing, measuring, enunciating, inferring, proving, demonstrating, experimenting, publishing, discussing, exposing, teaching, writing, rewarding, criticizing and even snubbing and attacking, which need to be evaluated along with their results (Olivé 2004: 75).

The emphasis on observing the specific situations and events in which such agreements are carried out gave a very radical twist to the social study of science. One of its aspects focused on scientific controversies as a point of reference for the study of the formation of consensus, that is, in the mechanisms by which the pretensions of knowledge come to be accepted as true (Brannigan 1981) (Collins 1981). On the other hand, Latour and Woolgar (1986) chose to dedicate themselves to the direct observation of the real place of scientific work. Their main finding was that when scientists themselves explain their behavior they rarely appeal to Mertonian-style norms; rather, they resort to economic terms such as credit, investment and profits (Labarca 2001). It is surprising that the authors of Laboratory Life, one of the most cited works in the specialized bibliography together with Bloor's book, Knowledge and Social Imaginary, (Bloor 1998) have placed such high hopes that actors explicit the rules that underlie their scientific work. A similar position would seem to assume Knorr-Cetina (2005), when affirms that "the products of science are contextually specific constructions that bear the marks of the situational contingency and the structure of interests of the process by which they are generated" (Knorr-Cetina 2005: 60-61).

I understand that such expectations are unbalanced, since, viewed sociologically, whatever the phenomenon studied, in most cases' norms' are never in sight or part of individuals' awareness of the reasons that move them to act. As Alfred Schutz pointed out, it is necessary to distance oneself from the actor in order to observe it and develop a conceptual framework based on the objectification of the subjective 
matrix of meaning that the protagonists of a social fact attribute to the action. In this connection, the distinction made by Alfred Schutz (1974a) between the set of reasons "for" and "why" (Schutz 1974a: 88-108) is not free. Since the first ones are those that the actor generally recognizes as the purpose of his behavior, that which consciously motivates him to act. On the contrary, the reasons "why" rarely be consciously perceived, since they are experiences that were inscribed in their social biography and can only be rescued through an analytical revival. Precisely, these are the kinds of motives that are sociologically more meaningful, since lead the researcher identify the life background most revealing of the sense attached to the action of the observed subjects. Through them we access the sedimentation of previous subjective experiences that lead people to act in the way that is most 'natural' in a given social field (Bartolucci 2011).

The support given by the sociology of Max Weber (1994) to the conception of Schutz is categorical. When he investigated the relations between the ethics of ancient Protestantism and the development of capitalism, he did so without expecting to find in any of the founders or representatives of these religious communities expressions of what he called the "capitalist spirit". On the contrary, he did not even suppose that some of them would have considered as an ethical value to aspire to worldly goods as an end in itself. The aims and practical effects of his doctrine were consequences of purely religious motives. The cultural effects of the Reformation were, for Weber's point of view (Weber 1994), involuntary and unwanted consequences of the work of the reformers, sometimes very distant or even opposed to what they imagined (Weber 1994: 105). Defining the current capitalist system as a cosmos in which the individual is born and is for him, at least as an individual, a shell virtually irreplaceable, within which he has to live, validated this same criterion. The 'market' imposes on the individual the rules of his economic activity. The manufacturer who acts against these rules, consciously or not, as the worker who does not want or cannot adapt to them, regardless of the knowledge available, will inevitably be affected from an economic point of view (Weber 1994: 63).

In spite of the "strong program" search for social factors within scientific activity, this "multiform attempt to desacralize science" (Vessuri 1991: 62) failed to satisfactorily-solve the criticized dissociation between the cognitive and the social. The main flaw of this innovative orientation, according to Mario Bunge, was to pretend that the content or meaning of any scientific idea is social. In his view, the fact that Latour or Woolgar found an interconnection between knowledge and the laboratory does not authorize them to transfer it to all aspects of scientific life, and even less the attributions made by Latour denying the distinction between context and content, or those elaborated by Woolgar in merging praxis with discourse (Valero 2004: 108-109). Bunge agrees that it is clear that men of science do not live in a social vacuum and that the separation 
between cognitive and practical dimension is purely analytical; but from there to assume the expositions of the strong program of sociology of science, for him it would be like admitting that because men need air to breathe it would allow us to infer that we are determined by the atmosphere (Otero 1998: 89-94).

\section{In Way of Conclusion: The Social Foundation of Science}

Bunge's position brings to light an old polemic of historical and social studies on the science, between "internalist \& externalist" conception of history, on which it is opportune to fix a position. From the 'externalist' perspective, science is reduced to the condition of a mere epiphenomenon of social and economic conditions, or as a direct expression of economic and social relations at a given time. The 'internalist' approach, on the other hand, limits the analysis of the development of science to the pure movement of scientific ideas, theories, and methods and denies their connection with the material and spiritual life of society. From this point of view, science represents an isolated, completely autonomous sphere that does not depend on social and economic conditions. It seems reasonable to think that no specific case is exactly subjected to any of the models placed in antithesis (Otero 1998: 89-94). Khun's message in an attempt to soften the harshness of the dichotomy is eloquent:

Both historians in general and historians of science repeatedly complain that my relation to scientific development rests exclusively on factors internal to the sciences themselves; that I fail to inscribe the scientific communities in the society in which they are sustained and from which their members are extracted; and that I therefore seem to believe that scientific development is immune to the influences of the social, economic, religious and philosophical means in which it is developed. Of course, my book has little to say about such external influences, but this should not be construed as a denial that they exist (Kuhn 1982, quoted in Otero 1998:92).

In affinity with Kuhn's opinion and in accordance with the argument developed in this essay, an adequate sociological elucidation of the social nature of science demands to consider the problem in its proper terms. Same damage makes the over determination of society on scientific facts as their ignorance. As a principle, it is not necessary to bring both positions to such extremes. When it is said that the development of science has social bases, it is not necessary to think of rigid and direct determinations. Likewise, in affirming that scientific prerequisites are created within science itself, there is no reason to deny that they are human constructions situated socially and historically. Returning to the idea that the technical basis of science and its ethical 
foundations are on the same plane, the challenge of any sociological study of science is to elucidate its reality as a result of a peculiar cultural process and to identify the technical and moral factors that legitimize it. In other words, observing and analyzing sociologically the scientific facts implies recognizing the basis of social foundation that sustains its cognitive elements.

Their epistemic duties express cognitive criteria constructed, validated and transmitted socially. These are the assumptions that lie at the basis of Merton's famous norms and scientific paradigms, as Kuhn would later say. The set of values that govern scientific practice have been 'naturalized' to such an extent in the community that are not in sight of the actors. Moral adherence occurs because they are believed to be good in themselves, not because they functionally regulate the distribution of opportunities and rewards (Merton 1973: 225). Merton (1973) refuted the possibility that his position would be criticized on the basis of countless counterexamples, arguing that this would be possible only if the level of institutional norms was confused with the level of individual behavior. Similarly, the fact that many drivers frequently violate traffic regulations does not eliminate the existence of a set of traffic regulations, which allow us to judge the behavior of others as drivers (Márquez and Vilaró 2014: 84).

The same is true with norms and values that define the scientific ethos. The ethical obligation to make observations, hypotheses and theories public, subject to inter subjective and international testing, is a constituent part of scientific communities. That is why scientists have developed formal languages, capable of cross culturally expressing knowledge (Echeverria 2004: 36). The set of cognitive representations, such as observing, measuring, enunciating, inferring, proving, etc., enclose the sense of being what they are and doing what they do. Everyday life is what it is and develops with all its differences and nuances, because the practical exercise of the profession allows them to understand or dissent in accordance with the reciprocal expectations that are configured within a frame of reference that is as habitual as significant. This reflexivity constitutive of scientific activity implies an inseparable conjugation of the practical and the cognitive, of the moral and the technicat. 


\section{REFERENCES}

Bartolucci, J. (2011). El desarrollo de la ciencia en México. De la antigua astronomía de posición a la astrofísica moderna. Saarbrücken, Alemania: Editorial Académica Española.

Bloor, D. (1998). Conocimiento e imaginario social, Barcelona, España: Gedisa.

Bourdieu, P. (2003). El oficio de científico. Ciencia de la ciencia y reflexividad. Barcelona, España: Editoriat Anagrama.

Brannigan, A. (1981). The social basis of scientific discoveries, New York: Cambridge University Press.

Bunge, M. (1991). "Una caricatura de la ciencia: La novísima sociología de la Ciencia." Interciencia 16 (2): 60-68.

Collins, H. (1981). "Son of Seven Sexes: The Social Destruction of a Physical Phenomenon" Social Studies of Science, Especial Issue: 'Knowledge and Controversy: Studies of Modern Natural Science' 11 (1): 33-62.

Crozier, M. and Erhard Friedberg. (1990). El actor y el sistema. Las restricciones de la acción colectiva. Ciudad de México: Editorial Alianza.

Echeverría, J. (2004). "El ethos de la ciencia, a partir de Merton". Jesús Valero, (Coord.). Sociología de la Ciencia. Madrid: Editorial EDAF: 31-56.

Fernándes, M. y Cristobal Torres. (2009). "La Ciencia como Institución Social.

Clásicos y Modernos Institucionalismos." Sociología de la Ciencia. ARBOR, Ciencia Pensamiento y Cultura 185 (738): 663-687.

Ferreira, M. (2007). "La sociología del conocimiento científico: una perspectiva crítica de futuro." Nómadas. Revista Crítica de Ciencias Sociales y Jurídicas 16 (2): 231-234.

Ferreira, M. (2008). "El conocimiento científico como actividad. Una aproximación sociológica a un sujeto singular." Nómadas. Revista Crítica de Ciencias Sociales y Jurídicas 19: 245-260.

Iranzo, J. M. (1991). El giro sociológico en la teoría de la ciencia. ¿Una revolución en marcha? Madrid: Universidad Complutense de Madrid, Facultad de Ciencias Políticas y Sociología, Departamento de Sociología I (Cambio Social).

Knorr-Cetina, K. (2005). La fabricación del conocimiento. Un ensayo sobre el carácter constructivista y contextual de la ciencia. Quilmes: Universidad Nacional de Quilmes Editorial.

Kuhn, T. (1977). The Essential Tension. Chicago: The University of Chicago Press. 
Kuhn, T. (1980). La estructura de las revoluciones científicas. Ciudad de México: Breviarios, Fondo de Cultura Económica.

Latour, B. and Steve Woolgar. (1979). Laboratory Life, Beverly Hills: SAGE Publications.

Lomnitz, L. (1991). "El Congreso Científico: una perspectiva antropológica." Vuelta (59): 45-48.

Labarca, M. G. (2001). "El programa fuerte en sociología del conocimiento: Algunas consideraciones." Agora Philosophica, Revista Marplatense de Filosofía 2(4): 29-37.

Márquez, C. and Ignacio Vilaró. (2014). "La resistencia al programa fuerte en la sociología del conocimiento: la asepsia científica y la amenaza del relativismo." Revista Mexicana de Ciencias Políticas Sociales 59 (221): 77-98.

Merton, R. (1964). Teoría y Estructuras Sociales. Ciudad de México: Fondo de Cultura Económica.

Merton, R. $\left(1985^{\circ}\right)$. La sociología de la ciencia 1. Madrid: Alianza Editorial.

Merton, R. (1985b). La sociología de la ciencia 2. Madrid: Alianza Editorial.

Mills, W. (1975). La imaginación sociológica, Ciudad de México: Fondo de Cultura Económica.

Nola, R. (2004). "La sociología es un modo de adormecernos: el uso de Wittgenstein por la Sociología de la ciencia" en Jesús Valero, (Coord.). Sociología de la Ciencia. Madrid: Editorial EDAF: 141-189.

Olivé, L. (2004). "De la estructura normativa de la ciencia a las prácticas científicas". Jesús Valero, (Coord.). Sociología de la Ciencia. Madrid: Editorial EDAF: $57-80$.

Otero, E. (1998). "El 'Programa fuerte' en Sociología de la ciencia y sus críticos." Revista Austral de Ciencias Sociales 2: 89-94.

Popper, K. (1975). "La ciencia normal y sus peligros". Imre Lakatos and Alan Musgrave (Eds.), La crítica y el desarrollo del conocimiento científico. Barcelona: Grijalbo.

Popper, K. (1977). La Lógica de la Investigación Científica, Madrid: Editorial Tecnos.

Sarthou, F. (2013). "Perspectivas sociológicas del quehacer científico. Una revisión bibliográfica sobre los principales enfoques que explican el comportamiento de los investigadores." Nómadas. Revista Crítica de Ciencias Sociales y Jurídicas 38: 193-220.

Schutz, A. $\left(1974^{a}\right)$, El problema de la realidad social, Buenos Aires: Amorrortu. 
Schutz, A. (1974b), Estudios sobre teoría social, Buenos Aires: Amorrortu.

Weber, M. (1978). Ensayos sobre metodología sociológica. Buenos Aires: Amorrortu.

Weber, M. (1994). La ética protestante y el espíritu del capitalismo. Ciudad de México: Ediciones Coyoacán.

Valero, J. (2004). Sociología de la Ciencia, Madrid: Editorial EDAF.

Vessuri, H. (1991). "Perspectivas recientes en el estudio social de la ciencia." Interciencia 2 (16): 60-68.

Yahiel, N. (1975). "La Sociología de la Ciencia como una teoría sociológica determinada." Revista Mexicana de Sociología 37 (1): 55-80.

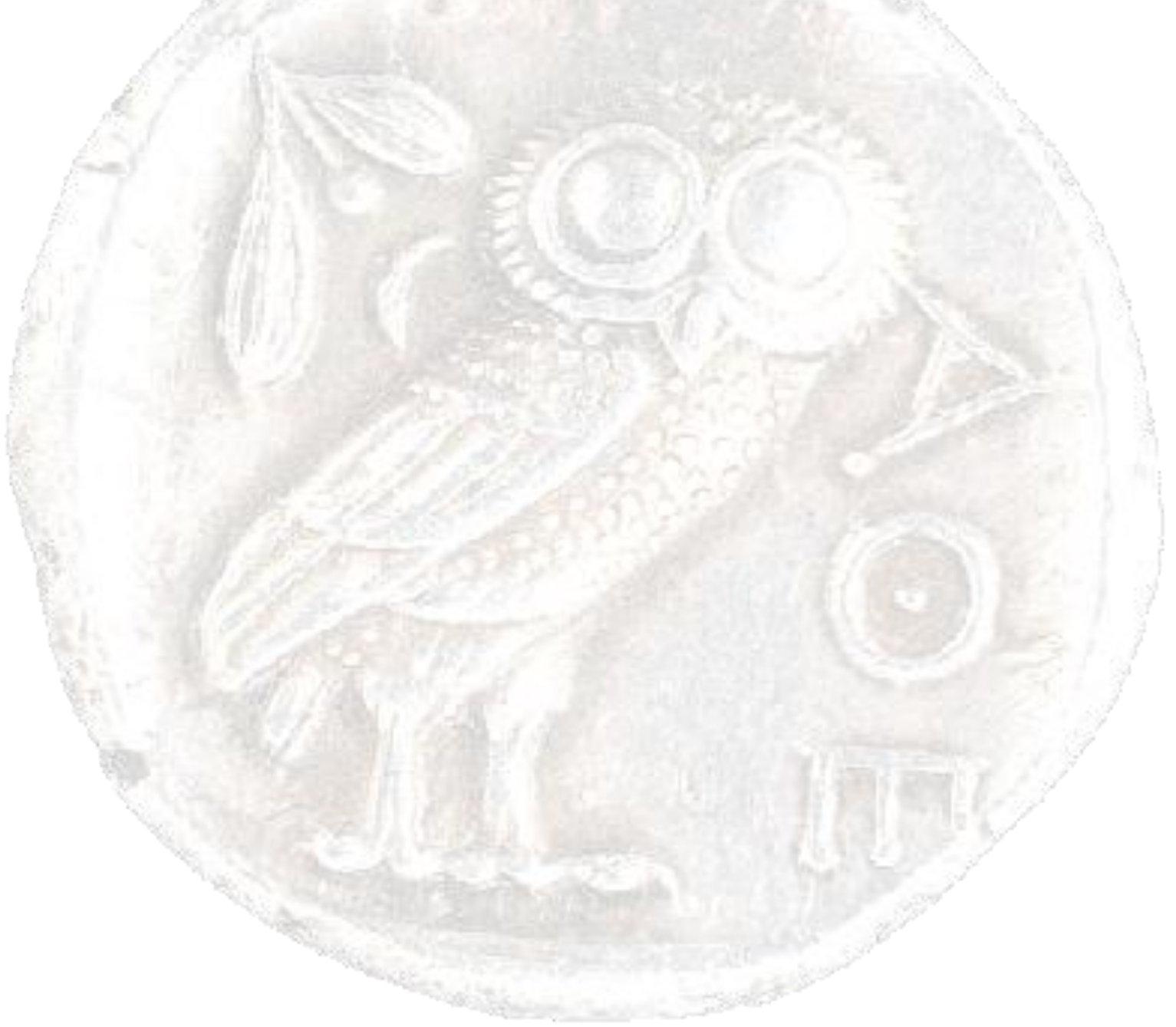

